\title{
PENINGKATAN HASIL BELAJAR PPKn TENTANG POLITIK LUAR NEGERI BEBAS AKTIF DENGAN METODE BRAINSTORMING
}

\author{
Sumarwoto \\ Universitas Wisnu Wardhana Malang \\ Email: langitpitu.harry@gmail.com
}

\begin{abstract}
The learning process is always gradual, starting from learning through signals, then through stimulus-response, chaining, learning verbally, learning to differentiate, learning concepts, to learning principles and principles. learn for problem solving. The result is capabilities, whether in the form of certain knowledge, attitudes, or skills. PPKn lessons are one of the lessons whose material continues to develop over time. The learning material requires the ability to analyze, generalize and the ability to remember, so it is often taught by some students. Based on the results of preliminary observations and interviews with PPKn subject teachers in class IX-A of SMPN 1 Pule Trenggalek, information was obtained that the average value of PPKn learning outcomes only reached an average of 54.2, specifically foreign policy material is free and active and this has not meet the learning completeness criteria set at 69 (KKM). There were only 10 students who scored $\geq 69$ or $36.7 \%$ and 20 students or $64.3 \%$ had not reached the KKM. So through this classroom action research, the researcher will apply the brainstorming learning method. The subjects of this study were students of class IX-A at SMPN 1 Pule Trenggalek in the 2019/2020 academic year with 30 students. From the results of the learning activities that have been carried out for two cycles, and based on all the discussions and analyzes that have been carried out, it can be concluded that the application of the brainstorming method can improve student learning achievement on PPKn material on free and active foreign policy. This is based on the post test score which continues to increase from the first to the second cycle. The application of the brainstorming method in PPKn learning about free and active foreign policy, begins with giving group assignments. Each group was assigned the task of discussing free and active foreign policy. In advanced learning, students complete assignments independently.
\end{abstract}

Keywords: Learning Outcomes, Foreign Policy, Brainstorming

Abstrak: Proses belajar selalu bertahap mulai dari belajar melalui tanda (signal), kemudian melalui rangsangan-reaksi (stimulus respons), belajar berangkai (chaining), belajar secara verbal, belajar membedakan (discrimination), belajar konsep, sampai kepada cara belajar prinsip dan belajar untuk pemecahan masalah. Hasilnya berupa kapabilitas, baik berupa pengetahuan, sikap, ataupun ketrampilan tertentu. Pelajaran PPKn adalah salah satu pelajaran yang materinya berkembang terus sejalan dengan berjalannya waktu. Materi pembelajarannya membutuhkan kemampuan untuk menganalisis, menggeneralisasi serta kemampuan mengingat, sehingga sering dianaktirikan oleh sebagian siswa. Berdasarkan hasil observasi awal dan wawancara dengan guru mata pelajaran PPKn di kelas IX-A SMPN 1 Pule Trenggalek, diperoleh informasi bahwa nilai rata-rata hasil belajar PPKn hanya mencapai rata-rata 54,2, khusus materi politik luar negeri bebas aktif dan ini belum memenuhi kriteria ketuntasan belajar yang ditetapkan sebesar 69 (KKM). Siswa yang memperoleh nilai $\geq 69$ hanya 10 orang atau 36,7\% dan siswa yang memperoleh nilai $<69$ sebanyak 20 orang atau $64,3 \%$ belum mencapai KKM. Maka melalui penelitian tindakan 
kelas ini, peneliti akan menerapkan metode pembelajaran brainstorming. Yang menjadi subjek penelitian ini adalah siswa kelas IX-A SMPN 1 Pule Trenggalek tahun pelajaran 2019/2020 dengan jumlah siswa 30 orang. Dari hasil kegiatan pembelajaran yang telah di lakukan selama dua siklus, dan berdasarkan seluruh pembahasan serta analisis yang telah dilakukan dapat disimpulkan bahwa penerapan metode brainstorming dapat meningkatkan prestasi belajar siswa pada materi PPKn tentang politik luar negeri bebas aktif. Hal ini berdasar atas nilai post test yang terus meningkat dari siklus pertama hingga kedua. Penerapan metode brainstorming dalam pembelajaran PPKn tentang politik luar negeri bebas aktif, diawali dengan memberikan tugas kelompok. Setiap kelompok mendapat tugas mendiskusikan politik luar negeri bebas aktif. Pada pembelajaran lanjutan, siswa menyelesaikan tugas secara mandiri.

Kata Kunci : Hasil Belajar, Politik Luar Negeri, Brainstorming

\section{PENDAHULUAN}

Metode pembelajaran yang

dipilih guru akan mempercepat

terjadinya perubahan

perilaku peserta didik. Pemilihan metode pembelajaran harus memperhatikan tingkat perkembangan mental peserta didik. Metode

pembelajaran yang sesuai dengan perkembangan mental anak turut menentukan evektifitas dan efesiensi proses belajar mengajar. Metode pembelajaran ceramah adalah metode yang harus ada dalam setiap pembelajaran. bagaimana guru akan menjelaskan sesuatu dan menginstruksikan sesuatu dalam pembelajaran, jika metode ceramah tidak disertakan dalam suatu kegiatan pembelajaran. Namun metode ceramah perlu dikombinasikan dengan metode yang memberikan kesempatan kepada siswa untuk turut aktif dalam pembelajaran. Konsep yang ditanamkan seorang guru kepada peserta didik dengan hanya menggunakan metode ceramah sangat minim melibatkan peserta didik. Lebihlebih konsep yang memerlukan daya analisis dan sintesis. Siswa akan hafal materi pembelajaran saja tanpa tahu hal yang harus dipahami dari materi itu.

Interaksi antara guru dan siswa dalam pembelajaran dapat menumbuhkembangkan motivasi pada peserta didik sehingga mau melakukan kegiatan belajar. Belajar adalah proses perubahan tingkah laku yang terjadi pada peserta didik baik yang sifatnya pengetahuan, sikap, ataupun ketrampilan yang terjadi secara bertahap dan permanen. Perubahan ini merupakan sesuatu yang diusahakan, dan tidak terjadi dengan sendirinya tanpa usaha apapun. Gagne berpendapat bahwa belajar merupakan suatu proses dari proses yang sederhana keproses yang kompleks. Oleh sebab itu, proses belajar selalu bertahap mulai dari belajar melalui tanda (signal), kemudian melalui rangsangan-reaksi (stimulus respons), belajar berangkai (chaining), belajar secara verbal, belajar membedakan (discrimination), belajar konsep, sampai kepada cara belajar prinsip dan belajar untuk pemecahan masalah. Hasilnya berupa kapabilitas, baik berupa pengetahuan, sikap, ataupun ketrampilan tertentu.

Pelajaran PPKn adalah salah satu pelajaran yang materinya berkembang terus sejalan dengan berjalannya waktu. Materi pembelajarannya membutuhkan kemampuan untuk menganalisis, menggeneralisasi serta kemampuan mengingat, sehingga sering dianaktirikan oleh sebagian siswa. Berdasarkan hasil observasi awal dan wawancara dengan guru mata pelajaran PPKn di kelas IX-A SMPN 1 Pule Trenggalek, diperoleh informasi bahwa nilai rata-rata hasil belajar PPKn tahun ajaran 2019/2020 pada 
semester ganjil (I) hanya mencapai rata-rata 54,2, khusus materi politik luar negeri bebas aktif dan ini belum memenuhi kriteria ketuntasan belajar yang ditetapkan sebesar 69 (KKM). Siswa yang memperoleh nilai $\geq 69$ hanya 10 orang atau $36,7 \%$ dan siswa yang memperoleh nilai $<69$ sebanyak 20 orang atau $64,3 \%$ belum mencapai KKM. Penyebab rendahnya hasil belajar PPKn, diperkirakan karena kurangnya keaktifan siswa saat mengikuti pembelajaran dan pada akhirnya mengakibatkan rendahnya pemahaman siswa terhadap mata pelajaran PPKn. Salah saatu materi ajar yang dirasakan masih cukup sulit dipahami siswa adalah politik luar negeri bebas aktif.

Maka melalui penelitian tindakan kelas ini, peneliti akan menerapkan metode pembelajaran brainstorming, sehingga interaksi belajar mengajar yang berlangsung dapat mencapai hasil yang diharapkan. Metode pembelajaran brainstorming adalah metode yang dilakukan dalam kelompok yang peserta didiknya memiliki latar belakang pengetahuan dan pengalaman yang berbeda-beda. Kegiatan ini dilakukan untuk menghimpun gagasan dan pendapat dalam rangka menentukan dan memilih berbagai pernyataan sebagai jawaban terhadap pertanyaan yang berkaitan dengan kebutuhan belajar, sumber-sumber, hambatan dan lain sebagainya (Sudjana, 2005:156).

\section{METODE \\ PENELITIAN Subjek \\ dan Lokasi Penelitian}

Yang menjadi subjek

penelitian ini

adalah siswa kelas IX-A SMPN 1 Pule Trenggalek tahun pelajaran 2019/2020 dengan jumlah siswa 30 orang. Dari seluruh siswa tersebut, penulis ambil seluruhnya sebagai sasaran penelitian. Siswa tersebut memiliki latar belakang yang berbeda-beda, baik dari kecerdasan atau intelegensi, perhatian, bakat, minat, motivasi, kematangan, kesiapan dan kelelahan maupun lingkungan keluarga dan lingkungan masyarakatnya.

\section{Rancangan \\ Penelitian}

Penelitian ini menggunakan penelitian tindakan kelas. Menurut Tim Pelatih Proyek PGSM, penelitian tindakan kelas adalah suatu bentuk kajian yang bersifat reflektif oleh pelaku tindakan yang dilakukan untuk meningkatkan kemantapan rasional dari tindakan mereka dalam melaksanakan tugas, memperdalam pemahaman terhadap tindakan-tindakan yang dilakukan itu, serta memperbaiki kondisi dimana praktek pembelajaran tersebut dilakukan (dalam Mukhlis, 2000: 3). Sedangkah menurut Mukhlis (2000: 5) penelitian tindakan kelas adalah suatu bentuk kajian yang bersifat sistematis reflektif oleh pelaku tindakan untuk memperbaiki kondisi pembelajaran yang dilakukan.

Sesuai dengan jenis penelitian yang dipilih, yaitu penelitian tindakan, maka penelitian ini menggunakan model penelitian tindakan dari Kemmis dan Taggart (dalam Sugiarti, 1997: 6), yaitu berbentuk spiral dari sklus yang satu ke siklus yang berikutnya. Setiap siklus meliputi planning (rencana), action (tindakan), observation (pengamatan), dan reflection (refleksi). Langkah pada siklus berikutnya adalah perncanaan yang sudah direvisi, tindakan, pengamatan, dan refleksi. Sebelum masuk pada siklus I dilakukan tindakan pendahuluan yang berupa identifikasi permasalahan.

\section{Data Aktivitas Belajar}

Data mengenai aktivitas siswa selama pembelajaran dengan metode brainstorming diambil dengan menggunakan lembar observasi dengan cara memberikan skor pada aspek 
aktivitas yang dilakukan oleh siswa sesuai dengan kriteria yang telah ditentukan. Data mengenai aktivitas siswa dalam proses belajar-mengajar dapat diuraikan berdasarkan siklus, sebegai berikut:

Tabel 1.

Skor Aktivitas Siswa Pertemuan I Siklus I

\begin{tabular}{|c|c|c|c|c|c|c|c|c|}
\hline \multirow{2}{*}{$\begin{array}{l}\mathbf{N} \\
0\end{array}$} & \multirow{2}{*}{ Keglatan } & \multicolumn{7}{|c|}{ Kelompok } \\
\hline & & 1 & 2 & 3 & 4 & 5 & 6 & 7 \\
\hline 1 & Siswa memperhatikan penjelasan & 2 & 3 & 2 & 3 & 3 & 3 & 2 \\
\hline 2 & Siswa selalu dalam kelompoknya & 1 & 3 & 2 & 3 & 3 & 3 & 3 \\
\hline 3 & Siswa aktif dalam kelompoknya & 3 & 2 & 3 & 2 & 3 & 3 & 1 \\
\hline 4 & $\begin{array}{l}\text { Siswa yang canggung dalam } \\
\text { kelompoknya }\end{array}$ & 3 & 3 & 3 & 2 & 3 & 4 & 3 \\
\hline 5 & Siswa berdiskusi dalam kelompoknya & 2 & 3 & 2 & 2 & 2 & 2 & 3 \\
\hline 6 & Siswa menyelesaikan masalah & 2 & 3 & 2 & 1 & 2 & 2 & 2 \\
\hline 7 & Siswa mengajukan pertanyaan & 2 & 2 & 3 & 2 & 3 & 3 & 1 \\
\hline 8 & $\begin{array}{l}\text { Ada rasa takut ketika nomor } \\
\text { anggotanya terpanggil }\end{array}$ & 2 & 3 & 3 & 2 & 3 & 2 & 2 \\
\hline 9 & $\begin{array}{l}\text { Siswa menjawab/ mempresentasikan } \\
\text { hasil kerja }\end{array}$ & 1 & 2 & 2 & 2 & 2 & 2 & 4 \\
\hline 10 & Siswa membuat rangkuman & 1 & 2 & 2 & 2 & 2 & 3 & 1 \\
\hline \multicolumn{2}{|c|}{ Rata-Rata Aktivitas Kelompok } & 1,9 & 2,6 & 2,4 & 2,1 & 2,6 & 2,7 & 2,5 \\
\hline \multicolumn{2}{|c|}{ Kategori } & Kurang & Cukup & Cukup & Cukup & Cukup & Cukup & Cukup \\
\hline
\end{tabular}

Berdasarkan tabel 1 menunjukkan rata- rata aktivitas siswa pada pertemuan I siklus I tergolong rendah, dimana kelompok 1 mempunyai ratarata 1,9; kelompok 2 sebesar 2,6; kelompok 3 sebesar 2,4; kelompok 4 sebesar 2,1; kelompok 5 sebesar
2,6; kelompok 6 sebesar 2,7 dan kelompok 7 sebesar 2,5. Dari data tersebut, dapat dikategorikan menjadi 2 kategori yakni kategori kurang seperti kelompok 1 dan kategori cukup seperti kelompok 2, kelompok 3, kelompok 5 , kelompok 6, dan kelompok 7.

Tabel 2.

Skor Aktivitas Siswa Pertemuan II Siklus I

\begin{tabular}{|c|c|c|c|c|c|c|c|c|}
\hline \multirow[t]{2}{*}{ No } & \multirow{2}{*}{ Keglatan } & \multicolumn{7}{|c|}{ Kelompok } \\
\hline & & 1 & 2 & 3 & 4 & 5 & 6 & 7 \\
\hline 1 & Siswa memperhatikan penjelasan & 3 & 4 & 3 & 4 & 4 & 4 & 4 \\
\hline 2 & Siswa selalu dalam kelompoknya & 3 & 4 & 3 & 4 & 3 & 4 & 4 \\
\hline 3 & Siswa aktif dalam kelompoknya & 4 & 3 & 3 & 4 & 3 & 4 & 3 \\
\hline 4 & $\begin{array}{l}\text { Siswa yang canggung dalam } \\
\text { kelompoknya }\end{array}$ & 4 & 1 & 2 & 3 & 3 & 3 & 3 \\
\hline 5 & Siswa berdiskusi dalam kelompoknya & 4 & 3 & 2 & 4 & 4 & 4 & 3 \\
\hline 6 & Siswa menyelesaikan masalah & 4 & 1 & 2 & 3 & 3 & 3 & 2 \\
\hline 7 & Siswa mengajukan pertanyaan & 3 & 2 & 2 & 3 & 3 & 3 & 3 \\
\hline 8 & $\begin{array}{l}\text { Ada rasa takut ketika nomor } \\
\text { anggotanya terpanggil }\end{array}$ & 4 & 1 & 2 & 1 & 4 & 2 & 2 \\
\hline 9 & $\begin{array}{l}\text { Siswa menjawab/ mempresentasikan } \\
\text { hasil kerja }\end{array}$ & 3 & 3 & 3 & 3 & 3 & 3 & 3 \\
\hline 10 & Siswa membuat rangkuman & 3 & 1 & 1 & 2 & 2 & 2 & 1 \\
\hline \multirow{2}{*}{\multicolumn{2}{|c|}{ Rata-Rata Aktivitas Kelompok }} & 3,5 & 2,6 & 2,3 & 3,1 & 3,2 & 3,2 & 2,8 \\
\hline & Kategori & Baik & Cukup & Cukup & Baik & Baik & Baik & Baik \\
\hline
\end{tabular}

Berdasarkan tabel: 2 menunjukkan rata-rata aktivitas siswa pada pertemuan II siklus I tergolong tinggi, dimana kelompok 1 mempunyai rata-rata 3,5; kelompok 2 sebesar 2,6;

kelompok 3 sebesar 2,3; kelompok 4 sebesar 3,1; kelompok 5 sebesar 3,2; kelompok 6 sebesar 3,2 dan kelompok 7 sebesar 2,8. Dari data tersebut, dapat dikategorikan menjadi 2 
kategori yakni kategori cukup seperti kelompok 2 dan kelompok 3 serta kategori baik seperti kelompok 1, kelompok 4, kelompok 5, kelompok 6, dan kelompok 7. Dari tabel tersebut dapat dilihat peningkatan aktivitas siklus I dari kategori kurang menjadi cukup dan kategori cukup menjadi baik.

Untuk mendapatkan gambaran rata- rata aktivitas belajar siswa pada siklus II dapat dilihat pada tabel 3 berikut:

Tabel 3.

Skor Aktivitas Siswa Pertemuan I Siklus II

\begin{tabular}{|c|c|c|c|c|c|c|c|c|}
\hline \multirow{2}{*}{$\begin{array}{l}\mathbf{N} \\
\mathbf{0}\end{array}$} & \multirow{2}{*}{ Kegiatan } & \multicolumn{7}{|c|}{ Kelompok } \\
\hline & & 1 & 2 & 3 & 4 & 5 & 6 & 7 \\
\hline 1 & Siswa memperhatikan penjelasan & 4 & 3 & 4 & 4 & 3 & 3 & 3 \\
\hline 2 & Siswa selalu dalam kelompoknya & 3 & 3 & 3 & 4 & 2 & 3 & 4 \\
\hline 3 & Siswa aktif dalam kelompoknya & 3 & 3 & 4 & 4 & 3 & 3 & 3 \\
\hline 4 & $\begin{array}{l}\text { Siswa yang canggung dalam } \\
\text { kelompoknya }\end{array}$ & 4 & 2 & 2 & 1 & 2 & 2 & 1 \\
\hline 5 & $\begin{array}{l}\text { Siswa berdiskusi dalam } \\
\text { kelompoknya }\end{array}$ & 4 & 2 & 4 & 3 & 3 & 3 & 4 \\
\hline 6 & Siswa menyelesaikan masalah & 4 & 2 & 2 & 3 & 2 & 2 & 2 \\
\hline 7 & Siswa mengajukan pertanyaan & 3 & 3 & 2 & 2 & 3 & 2 & 2 \\
\hline 8 & $\begin{array}{l}\text { Ada rasa takut ketika nomor } \\
\text { anggotanya terpanggil }\end{array}$ & 3 & 3 & 3 & 2 & 2 & 2 & 1 \\
\hline 9 & $\begin{array}{l}\text { Siswa menjawab/ } \\
\text { mempresentasikan hasil kerja }\end{array}$ & 4 & 3 & 3 & 2 & 2 & 3 & 3 \\
\hline 10 & Siswa membuat rangkuman & 3 & 3 & 4 & 2 & 2 & 2 & 2 \\
\hline \multicolumn{2}{|c|}{ Rata-Rata Aktivitas Kelompok } & 3,0 & 2,7 & 3,1 & 2,7 & 2,4 & 2,5 & 2.5 \\
\hline \multicolumn{2}{|c|}{ Kategori } & Baik & Cukup & Baik & Cukup & cukup & cukup & cukup \\
\hline
\end{tabular}

Berdasarkan tabel: 3 menunjukkan rata-rata aktivitas siswa pada pertemuan I siklus II tergolong tinggi karena tidak ada aktivitas yang tergolong kurang, dimana kelompok 1 mempunyai rata-rata 3,0 ; kelompok 2 sebesar 2,7; kelompok 3 sebesar 3,1; kelompok 4 sebesar 2,7; kelompok 5 sebesar 2,4; kelompok 6 sebesar 2,5 dan kelompok 7 sebesar 2,5. Dari data tersebut, dapat dikategorikan menjadi 2 kategori yakni kategori cukup seperti kelompok 2, kelompok 4, kelompok 5,kelompok 6 dan kelompok 7 serta kategori baik seperti kelompok1 dan kelompok 3 .

Tabel 4.

Skor Aktivitas Siswa Pertemuan II Siklus II

\begin{tabular}{|c|c|c|c|c|c|c|c|c|}
\hline \multirow{2}{*}{$\mathbf{N}$} & \multirow{2}{*}{ Kegiatan } & \multicolumn{7}{|c|}{ Kelompok } \\
\hline & & 1 & 2 & 3 & 4 & 5 & 6 & 7 \\
\hline 1 & Siswa memperhatikan penjelasan & 3 & 4 & 4 & 4 & 4 & 4 & 4 \\
\hline 2 & Siswa selalu dalam kelompoknya & 3 & 4 & 3 & 4 & 4 & 3 & 4 \\
\hline 3 & Siswa aktif dalam kelompoknya & 4 & 4 & 4 & 4 & 3 & 4 & 4 \\
\hline 4 & $\begin{array}{l}\text { Siswa yang canggung dalam } \\
\text { kelompoknya }\end{array}$ & 2 & 2 & 3 & 3 & 2 & 3 & 4 \\
\hline 5 & $\begin{array}{l}\text { Siswa berdiskusi dalam } \\
\text { kelompoknya }\end{array}$ & 2 & 2 & 3 & 3 & 4 & 4 & 4 \\
\hline 6 & Siswa menyelesaikan masalah & 2 & 2 & 4 & 3 & 2 & 3 & 3 \\
\hline 7 & Siswa mengajukan pertanyaan & 2 & 4 & 3 & 3 & 4 & 2 & 4 \\
\hline 8 & $\begin{array}{l}\text { Ada rasa takut ketika nomor } \\
\text { anggotanya terpanggil }\end{array}$ & 2 & 2 & 2 & 2 & 3 & 4 & 4 \\
\hline 9 & $\begin{array}{l}\text { Siswa menjawab/ } \\
\text { mempresentasikan hasil kerja }\end{array}$ & 2 & 3 & 4 & 1 & 2 & 3 & 4 \\
\hline 10 & Siswa membuat rangkuman & 4 & 4 & 1 & 4 & 3 & 2 & 4 \\
\hline \multicolumn{2}{|c|}{ Rata-Rata Aktivitas Kelompok } & 2,6 & 3,1 & 3,2 & 3,1 & 3,1 & 3,2 & 3,9 \\
\hline \multicolumn{2}{|c|}{ Kategori } & Cukup & Baik & Baik & Baik & Baik & Baik & Baik \\
\hline
\end{tabular}


Berdasarkan tabel: 4 di atas, menunjukkan rata-rata aktivitas siswa mengalami peningkatan, yang terlihat dari rata-rata aktivitas siswa setiap kelompok, dimana kelompok 1 sebesar 2,6; kelompok 2 sebesar 3,1; kelompok 3 sebesar 3,2; kelompok 4 sebesar 3,1; kelompok 5 sebesar 3,1; kelompok 6 sebesar 3,2 dan kelompok 7 sebesar
3,9. Dari data tersebut, dapat dikategorikan menjadi 2 kategori yakni kategori cukup seperti kelompok 1 dan kelompok 7 dan kategori baik seperti kelompok 2, kelompok 3, kelompok 4, kelompok 5, kelompok 6 dan kelompok 7. Untuk melihat distribusi rata-rata aktivitas siswa pada setiap siklus, dapat dilihat pada tabel 5 sebagai berikut:

Tabel 5.

Distribusi Rata-rata Skor Aktivitas Siswa

\begin{tabular}{llcccc} 
N & \multicolumn{1}{c}{ Aspek Yang Dinilai } & \multicolumn{3}{c}{ Siklus } \\
o & \multicolumn{1}{c}{ I } & Kategori & II & Kategori \\
\hline 1 & Siswa memperhatikan penjelasan & 3,9 & Baik & 3,9 & Baik \\
\hline 2 & Siswa selalu dalam kelompoknya & 3,7 & Baik & 3,6 & Baik \\
\hline 3 & Siswa aktif dalam kelompoknya & 3,6 & Baik & 4,0 & Sangat baik \\
\hline 4 & $\begin{array}{l}\text { Siswa yang canggung dalam } \\
\text { kelompoknya }\end{array}$ & 2,4 & Cukup & 2,4 & Cukup \\
\hline 5 & Siswa berdiskusi dalam kelompoknya & 3,4 & Baik & 4,0 & Sangat baik \\
\hline 6 & Siswa menyelesaikan masalah & 2,7 & Cukup & 2,7 & Cukup \\
\hline 7 & Siswa mengajukan pertanyaan & 2,4 & Cukup & 3,0 & Baik \\
\hline 8 & $\begin{array}{l}\text { Ada rasa takut ketika nomor } \\
\text { anggotanya terpanggil }\end{array}$ & 2,0 & Kurang & 2,3 & Cukup \\
\hline 9 & $\begin{array}{l}\text { Siswa menjawab/ mempresentasikan } \\
\text { hasil kerja }\end{array}$ & 3,7 & Baik & 2,7 & Cukup \\
\hline 10 & Siswa membuat rangkuman & 1,3 & Kurang & 3,0 & Baik \\
\hline Rata-Rata Aktivitas Siswa & 2,9 & & 3,2 & \\
\hline Kategori & Cukup & & Baik & \\
\hline
\end{tabular}

Berdasarkan tabel: 5 di atas, menunjukkan rata-rata skor persatuan aktivitas siswa persiklus cenderung mengalami peningkatan ke arah yang lebih baik, dimana pada siklus I rata-rata skor persatuan aktivitas siswa umumnya berada pada kategori cukup, sedangkan pada siklus II rata-rata skor persatuan aktivitas siswa umumnya berada pada kategori baik, dengan rata-rata aktivitas siswa pada siklus I sebesar 2,9 meningkat sebesar 0,25 pada siklus II atau meningkat menjadi 3,2. Selain itu juga, pada siklus II ini, ada beberapa aktivitas siswa yang berhasil ditingkatkan dari kategori kurang menjadi kategori baik. Selain itu juga penigkatan aktivitas sebesar 3,2 menyatakan bahwa dalam satu kelompok terdapat satu sampai dua siswa kurang mampi menerapkan semua satuan aktivitas yang dinilai, sedangkan 2,9 menyatakan bahwa dalam satu kelompok terdapat tiga sampai empat kurang mampu menerapkan semua satuan aktivitas yang dinilai.

\section{Data Aktivitas}

\section{Guru}

Untuk mendapatkan gambaran aktivitas guru dalam mengelola pembelajaran dengan menggunakan metode brainstorming pada materi ajar oolitik luar negeri bebas aktif dapat dilihat pada tabel: 6 berikut: 
Tabel 6.

Skor Aktivitas Guru Siklus I

\begin{tabular}{clcc} 
No Aspek Yang Diamati & \multicolumn{2}{c}{ Pertemuan } \\
& & I & II \\
\hline 1 & Menjelaskan langkah-langkap pembelajaran & 2 & 3 \\
\hline 2 & Memberikan motivasi & 2 & 4 \\
\hline 3 & Menyampaikan tujuan pembelajaran & 2 & 3 \\
\hline 4 & Memberi apersepsi & 2 & 3 \\
\hline 5 & Mengorganisasi siswa dalam kelompok & 3 & 2 \\
\hline 6 & Menyiapkan lembar kerja & 3 & 4 \\
\hline 7 & Menjelaskan cara kerja dalam lembar kerja & 3 & 4 \\
\hline 8 & Meminta siswa berdiskusi dalam menjelaskan lembar kerja & 4 & 4 \\
\hline 9 & Membimbing kelompok menyelesaikan masalah & 4 & 3 \\
\hline 10 & Mengamati siswa bekerja dalam kelompoknya & 3 & 3 \\
\hline 11 & Membimbing siswa dalam mempresentasikan hasil kerja & 4 & 3 \\
\hline 12 & Memberikan penghargaan & 1 & 2 \\
\hline 13 & Mengarahkan siswa kejawaban yang benar & 3 & 4 \\
\hline 14 & Membimbing siswa membuat rangkuman & 2 & 2 \\
\hline Rata-Rata Aktivitas Guru & 2,7 & 3,1 \\
\hline Kategori & Cukup & Baik \\
\hline
\end{tabular}

Berdasarkan tabel: 6 di atas, menunjukkan rata-rata aktivitas guru dalam mengelola pembelajaran pada siklus I tergolong rendah, dimana ada beberapa aspek pembelajaran yang kurang diperhatikan guru untuk dilaksanakan seperti memotivasi siswa untuk belajar, menyampaikan tujuan/indikator yang harus dicapai dalam pembelajaran, memberikan penghargaan kepada kelompok yang memperoleh hasil terbaik, dan menyuruh siswa membuat rangkuman. Rata-rata aktivitas guru pada pertemuan I siklus I adalah 2,7 yang berkategori cukup.

Pada pertemuan II didapat data yang menunjukkan bahwa rata-rata aktivitas guru dalam mengelola pembelajaran pada siklus I tergolong tinggi, dimana ada beberapa aspek pembelajaran yang telah diperhatikan guru untuk dilaksanakan seperti memotivasi siswa untuk belajar, menyampaikan tujuan/indikator yang harus dicapai dalam pembelajaran, memberikan penghargaan kepada kelompok yang memperoleh hasil terbaik. Rata-rata aktivitas guru pada pertemuan II siklus I adalah 3,1 yang berkategori cukup. Dalam hal ini untuk siklus I sudah mengalami sedikit peningkatan dari 2,7 meningkat sebesar 3,1 yang artinya ada beberapa aspek yang dinilai mengalami peningkatan seperti aspek 2, 3, dan 5 . Untuk mendapatkan gambaran aktivitas guru dalam mengelola pembelajaran dengan menggunakan metode brainstorming pada siklus II dapat dilihat pada tabel: 7 berikut 
Tabel 7.

Skor Aktivitas Guru Siklus II

\begin{tabular}{clcc}
\hline \multirow{2}{*}{ No Aspek Yang Diamati } & \multicolumn{2}{c}{ Pertemuan } \\
\cline { 3 - 4 } & & I & II \\
\hline 1 & Menjelaskan langkah-langkap pembelajaran & 3 & 3 \\
\hline 2 & Memberikan motivasi & 3 & 3 \\
\hline 3 & Menyampaikan tujuan pembelajaran & 4 & 4 \\
\hline 4 & Memberi apersepsi & 2 & 2 \\
\hline 5 & Mengorganisasi siswa dalam kelompok & 3 & 4 \\
\hline 6 & Menyiapkan lembar kerja & 4 & 4 \\
\hline 7 & Menjelaskan cara kerja dalam lembar kerja & 4 & 4 \\
\hline 8 & Meminta siswa berdiskusi dalam menjelaskan lembar kerja & 4 & 4 \\
\hline 9 & Membimbing kelompok menyelesaikan masalah & 3 & 3 \\
\hline 10 & Mengamati siswa bekerja dalam kelompoknya & 3 & 4 \\
\hline 11 & Membimbing siswa dalam mempresentasikan hasil kerja & 4 & 3 \\
\hline 12 & Memberikan penghargaan & 2 & 3 \\
\hline 13 & Mengarahkan siswa kejawaban yang benar & 3 & 3 \\
\hline 14 & Membimbing siswa membuat rangkuman & 2 & 3 \\
\hline Rata-Rata Aktivitas Guru & 3,1 & 3,4 \\
\hline Kategori & Baik & Baik \\
\hline
\end{tabular}

Berdasarkan tabel: 7 di atas, tampak bahwa aktivitas guru sudah menunjukkan peningkatan dari siklus I, dimana rata-rata aktivitas guru dalam mengelola pembelajaran pada siklus II adalah sebesar 3,4 yang berkategori baik. Hal ini menujukkan bahwa guru telah menerapkan metode brainstorming pada materi ajar politik luar negeri bebas aktif dengan baik.

\section{HASIL DAN PEMBAHASAN}

Data Hasil Belajar Data hasil belajar tes awal, tes siklus I, dan tes siklus II, sebagai berikut:
Tabel 8.

Rekap Hasil Belajar

\begin{tabular}{|c|c|c|c|c|c|}
\hline No & $\begin{array}{l}\text { Kelo- } \\
\text { mpok }\end{array}$ & $\begin{array}{l}\text { Nama } \\
\text { Siswa }\end{array}$ & $\begin{array}{c}\text { Tes } \\
\text { Awal }\end{array}$ & $\begin{array}{c}\text { Tes } \\
\text { Siklus } \\
\text { I } \\
\end{array}$ & $\begin{array}{c}\text { Tes } \\
\text { Siklus } \\
\text { II } \\
\end{array}$ \\
\hline 1 & \multirow{5}{*}{ I } & Siswa 1 & 40 & 60 & 70 \\
\hline 2 & & Siswa 2 & 30 & 60 & 90 \\
\hline 3 & & Siswa 3 & 30 & 50 & 80 \\
\hline 4 & & Siswa 4 & 80 & 80 & 70 \\
\hline 5 & & Siswa 5 & 60 & 60 & 100 \\
\hline 6 & \multirow{4}{*}{ II } & Siswa 6 & 40 & 60 & 60 \\
\hline 7 & & Siswa 7 & 80 & 90 & 95 \\
\hline 8 & & Siswa 8 & 30 & 50 & 90 \\
\hline 9 & & Siswa 9 & 80 & 80 & 80 \\
\hline 10 & \multirow{4}{*}{ III } & Siswa 10 & 80 & 90 & 95 \\
\hline 11 & & Siswa 11 & 75 & 80 & 95 \\
\hline 12 & & Siswa 12 & 70 & 80 & 85 \\
\hline 13 & & Siswa 13 & 40 & 60 & 70 \\
\hline 14 & \multirow{4}{*}{ IV } & Siswa 14 & 60 & 60 & 80 \\
\hline 15 & & Siswa 15 & 60 & 70 & 75 \\
\hline 16 & & Siswa 16 & 60 & 80 & 70 \\
\hline 17 & & Siswa 17 & 20 & 60 & 80 \\
\hline 18 & \multirow{4}{*}{ V } & Siswa 18 & 60 & 70 & 75 \\
\hline 19 & & Siswa 19 & 75 & 80 & 85 \\
\hline 20 & & Siswa 20 & 70 & 70 & 90 \\
\hline 21 & & Siswa 21 & 40 & 70 & 90 \\
\hline 22 & \multirow{5}{*}{ VI } & Siswa 22 & 40 & 70 & 80 \\
\hline 23 & & Siswa 23 & 40 & 70 & 80 \\
\hline 24 & & Siswa 24 & 30 & 70 & 80 \\
\hline 25 & & Siswa 25 & 55 & 70 & 80 \\
\hline 26 & & Siswa 26 & 30 & 60 & 75 \\
\hline 27 & \multirow{4}{*}{ VII } & Siswa 27 & 80 & 80 & 80 \\
\hline 28 & & Siswa 28 & 30 & 70 & 80 \\
\hline 29 & & Siswa 29 & 70 & 70 & 85 \\
\hline 30 & & Siswa 30 & 70 & 70 & 90 \\
\hline \multicolumn{2}{|c|}{ Jumlah } & & 1625 & 2090 & 2455 \\
\hline \multicolumn{2}{|c|}{ Rata-rata } & & 54,2 & 69,7 & 81,8 \\
\hline
\end{tabular}


Berdasarkan tabel: 8 di atas, kita dapat melihat bahwa hasil belajarPPKn pada materi politik luar negeri bebas aktif setelah diajar dengan menerapkan metode brainstorming menunjukkan adanya peningkatan baik dari tes awal maupun hasil belajar siswa pada setiap siklus, dimana rata- rata hasil belajar siswa pada siklus I adalah sebesar 69,7 dan rata-rata hasil belajar siswa pada siklus II sebesar 81,8. Adanya peningkatan hasil belajar PPKn siswa yang signifikan baik dari tes awal maupun hasil belajar siswa pada setiap siklus, dimana rata-rata hasil belajar siswa pada siklus I adalah sebesar 69,7 dengan nilai maksimum 90 dan nilai minimum 50 dan rata-rata hasil belajar siswa pada siklus II meningkat sebesar 81,8 dengan nilai maksimum 100 dan nilai minimum 60. Demikian pula pada rata-rata tes awal siswa yaitu 54,2 dengan nilai maksimum 80 dan nilai minimum 30. Adanya peningkatan jumlah siswa (\%) yang sudah tuntas secara klasikal pada setiap siklus, dimana pada siklus I terdapat $66,6 \%$ siswa yang sudah tuntas sedangkan pada siklus II terdapat $96,7 \%$ siswa yang sudah tuntas.

\section{Pembahasan}

Pelaksanaan siklus I dimulai hari Rabu, tanggal 9 Oktober 2019 dan berakhir pada hari Rabu, 16 Oktober 2019. Berdasarkan hasil analisis deskriptif terhadap aktivitas siswa pada siklus I menunjukkan bahwa rata-rata aktivitas siswa pada siklus I adalah sebesar 2,9 yang berkategori cukup. Pada siklus I juga terdapat aspek aktivitas siswa yang memiliki skor rendah yaitu membuat rangkuman tentang materi yang dipelajari. Salah satu faktor yang menyebabkan rendahnya aktivitas siswa pada siklus I tersebut karena siswa masih asing dengan model pembelajaran yang diterapkan yakni metode brainstorming yang merupakan hal baru bagi mereka, dan cenderung terbiasa dengan pembelajaran konvensional yang berpusat pada guru sehingga siswa masih ragu-ragu untuk menanyakan masalah yang belum dipahaminya baik pada teman sekelompoknya maupun pada guru, dan pada saat mempresentasikan jawabannya sebagian kelompok menolak karena mereka tidak siap untuk mempresentasikan jawabannya.

Di samping itu pula, adanya faktor lain seperti tingkah laku guru dalam pembelajaran yang belum mencirikan metode brainstorming. Rata-rata aktivitas guru dalam pembelajaran adalah 3,1 yang berkategori cukup baik. Rendahnya aktivitas guru dalam pembelajaran adalah disebabkan oleh suasana kelas yang pada saat itu sangat tidak terkendali dan adanya sebagian siswa yang tidak mau duduk dalam kelompok-kelompok yang telah ditentukan, sehingga sebagian waktu tersita untuk membenahi kelompok siswa. Siswa dilibatkan secara langsung dalam pembelajaran dengan cara bersentuhan secara langsung dengan objek pembelajaran, melalui kegiatan diskusi dalam kelompok kecil. Kemampuan siswa dalam mengajukan pertanyaan masih sangat kurang. Oleh karena itu, sebagian aktivitas guru dalam metode brainstorming kurang diperhatikan guru untuk dilaksanakan seperti berdiskusi dengan teman kelompoknya dalam menyelesaikan masalah dalam LKS, menjawab atau mempresentasikan hasil kerja kelompoknya di depan kelas dan membuat rangkuman tentang materi yang dipelajari. Seluruh indikator pengamatan masih belum mencapai skor yang diharapkan. Masih banyak siswa yang belum aktif bertanya. Masih banyak siswa siswa yang belum aktif dalam menjawab pertanyaan Secara umum, ketuntasan skenario pelaksanaan pembelajaran yang dilakukan guru pada siklus I baru mencapai $82,2 \%$

Untuk mengatasi hal tersebut, maka guru bersama peneliti melakukan analisis dan refleksi terhadap faktorfaktor yang menyebabkan rendahnya aktivitas siswa maupun aktivitas guru dalam pembelajaran dan disepakati adanya beberapa kelemahan guru dalam pengelolaan metode brainstorming di kelas khususnya materi politik luar negeri bebas aktif, yaitu: Guru belum dapat mengorganisasikan waktu dengan baik. Hal itu terlihat dari bertambahnya waktu yang dibutuhkan untuk kegiatan inti. Akibatnya kegiatan tanya jawab antara siswa/guru serta kegiatan merangkum materi yang sedianya dilaksanakan pada 10 menit terakhir, dilaksanakan dengan mengambil jam pulang. Pada saat pembagian kelompok, guru belum dapat mengorganisasikan siswa dengan baik sehigga suasana kelas menjadi gaduh dan 
pembagian kelompok tidak dapat berjalan lancar. Guru kurang mengorganisasikan siswa untuk belajar pada setiap kelompok, dalam hal ini mengarahkan siswa untuk menelaah LKS. Pada saat guru memanggil salah satu nomor kepala dan meminta siswa maju ke depan untuk mempresetasikan hasil kerjanya, ada beberapa siswa yang menolak untuk mewakili kelompoknya dan guru menuruti keinginan siswa tersebut.

Kemudian, peneliti bersama guru mata pelajaran melakukan analisis dan refleksi terhadap kelemahan-kelemahan pelaksanaan metode brainstorming oleh guru dan kaitannya dengan satuan aktivitas siswa yang dinilai. Dari hasil refleksi tersebut, kemudian ditentukan langkah-langkah perbaikan pada siklus II, diantaranyauru hendaknya mengorganisasikan dan memberikan motivasi kepada siswa dalam setiap kelompok untuk selalu belajar, membaca buku teks atau LKS dan selalu mendiskusikan masalah-masalah sehubungan dengan materi pembelajaran. Guru harus lebih mengefektifkan pemantauan terhadap kegiatan kelompok dan pembimbingan intensif dan merata kepada semua kelompok. Guru harus dapat memotivasi siswa dengan memberikan nilai dan hadiah berupa buku tulis dan pulpen kepada kelompok yang kinerjanya bagus, agar setiap kelompok berlomba untuk menjadi yang terbaik. Guru harus dapat bersikap lebih tegas terhadap semua siswa selama kegiatan pembelajaran berlangsung.

Sedangkan pelaksanaan siklus II ini dimulai hari Rabu, tanggal 23 Oktober 2019 dan berakhir pada hari Rabu, 30 Oktober

2019. Berdasarkan hasil analisis deskriptif terhadap aktivitas siswa pada siklus II menunjukkan adanya peningkatan aktivitas siswa yang sangat signifikan dari siklus I. Rata-rata aktivitas siswa untuk siklus I adalah sebesar 2,9 dengan kategori cukup meningkat pada siklus II menjadi sebesar 3,2 dengan kategori baik, dan untuk semua rata- rata persatuan aktivitas siswa juga mengalami peningkatan yang sangat baik. Selain itu juga, pada siklus II ini, ada beberapa aktivitas siswa yang berhasil ditingkatkan dari kategori kurang menjadi kategori baik diantaranya berdiskusi dengan teman kelompoknya dalam menyelesaikan masalah dalam LKS, menjawab atau mempresentasikan hasil kerja kelompoknya di depan kelas dan membuat rangkuman tentang materi yang dipelajari. Peningkatan rata-rata aktivitas siswa menandakan bahwa siswa mulai aktif dalam mengikuti metode brainstorming. Disamping itu pula adanya motivasi serta minat belajar siswa yang tinggi, disebabkan karena keterampilan guru memotivasi siswa dengan memberikan nilai dan hadiah berupa buku tulis dan pulpen kepada kelompok yang kinerjanya bagus dan kepada siswa yang mempunyai hasil belajar yang tinggi pada setiap siklus.

Peningkatan aktivitas belajar siswa tersebut juga dipengaruhi oleh adanya kemampuan guru dalam mengelola pembelajaran dengan model metode brainstorming, Rata-rata aktivitas guru mengalami peningkatan pula, dimana rata- rata aktivitas guru dalam mengelola metode brainstorming adalah sebesar 3,4 yang berkategori baik. Adanya peningkatan aktivitas guru dari siklus I menunjukkan bahwa guru sudah dapat mengelola pembelajaran dengan penerapan metode brainstorming.

Peningkatan rata-rata aktivitas siswa pada setiap siklus tersebut menandakan bahwa siswa mulai aktif dalam mengikuti

pembelajaran. Hasil observasi yang dilakukan peneliti menunjukkan bahwa pelaksanaan pembelajaran dengan penerapan metode brainstorming dapat memberikan hasil yang lebih baik walaupun masih terdapat satuan aktivitas yang tidak mengalami peningkatan yang signifikan dan tergolong dalam kategori cukup seperti aktivitas siswa dalam mengajukan pertanyaan kepada guru saat mengalami kesulitan dalam menyelesaikan masalah 
dalam LKS, namun siswa sudah aktif membantu rekan-rekan sekelompoknya untuk menyelesaikan soal-soal yang diberikan.

Berdasarkan hasil yang diperoleh pada tindakan siklus II, ketuntasan materi dan

hasil observasi, maka penelitian ini dihentikan pada tindakan siklus II. Indikator keberhasilan dalam segi proses sudah tercapai yaitu minimal $85 \%$ proses pelaksanaan tindakan telah sesuai dengan skenario pembelajaran. Berdasarkan hasil analisis deskriptif terhadap aktivitas siswa pada setiap siklus menunjukkan bahwa penerapan model metode brainstorming mampu meningkatkan aktivitas belajar siswa sehingga tampak bahwa pembelajaran yang dilakukan dalam penelitian ini lebih terpusat pada siswa (student centre), dimana peran guru dalam pembelajaran hanya bersifat sebagai mediator

\section{SIMPULAN}

Dari hasil kegiatan pembelajaran yang telah di lakukan selama dua siklus, dan berdasarkan seluruh pembahasan serta

analisis yang telah dilakukan dapat disimpulkan bahwa penerapan metode brainstorming dapat meningkatkan prestasi belajar PPKn tentang politik luar negeri bebas aktif. Hal ini berdasar atas nilai post test yang terus meningkat dari siklus pertama hingga kedua. Penerapan metode brainstorming dalam pembelajaran PPKn tentang politik luar negeri bebas aktif, diawali dengan memberikan tugas kelompok. Setiap kelompok mendapat tugas mendiskusikan politik luar negeri bebas aktif. Pada pembelajaran lanjutan, siswa menyelesaikan tugas secara mandiri.

\section{DAFTAR PUSTAKA}

Dalyono. (2009). Psikologi

Pendidikan.

Jakarta: Rineka Cipta.

Erman Suherman, dkk.(1999). Strategi

Pembelajaran

Matematika

Kontenporer. Jakarta: Universitas

Pendidikan Indonesia.
Gulo, W.( 2005). Metodologi

Penelitian, Jakarta : Penerbit

Buku Grasindo. Ibrahim, H.

Muslimin. 2001. Pembelajaran

Kooperatif. Surabaya : UNESA.

Roestiyah, N.K.(2001). Strategi

Belajar Mengajar. Jakarta: Rineka Cipta.

Rusman. (2012). Belajar dan

Pembelajaran Berbasis Komputer

Mengembangkan Profesionalisme

Guru Abad 21. Bandung:

Alfabeta.

Slavin, R.E. (2005). Cooperative

Learning. Bandung: Nusa Media.

Suciati, Dr. (2003). Belajar dan Pembelajaran. Modul 3. Motivasi dan Pembelajaran. Jakarta: Pusat Penerbitan Universitas Terbuka.

Sudjana, (2005). Metode \& Tehnik Pembelajaran Partisipatif.

Bandung . Falah Production

Sukmadinata, Nana Syaodih.(2004). Metode Penelitian Pendidikan. Bandung: PT. Remaja Rosdakarya.

Sugiyono. (2010). Metode

Penelitian Pendidikan. Bandung:

Alfabeta.

Suparno, A. Suhaenah. 2001.

Membangun Kompetensi

Belajar. Jakarta: Direktorat

Jenderal Pendidikan Tinggi

Departemen Pendidikan

Nasional.

Suryabrata, Sumadi. (2004).

Psikologi Pendidikan. Jakarta: Raja

Grafindo

Persa

da.

Syah, Muhibin. (2000). Psikologi

Pendidikan dengan Pendekatan

Baru. Bandung: Remaja Rosda

Karya.

Tijan, dkk. 2005. Peningkatan Kualitas

Proses dan Hasil Pembelajaran 
Humanis Vol. 13 No. 1

Mata Kuliah SSBI. Laporan

Penelitian. Semarang: SP4.

Wardani, Igak. (2001). Praktik

Mengajar.
Jakarta: Dirjen Dikti Depdikbud.

Wibawa, Basuki. (2003).

Penelitian

Tindakan Kelas. Jakarta:

Depdiknas. 